\title{
PARENTAL BEHAVIORS IN THE CONTEXT OF ADOLESCENT DISCLOSURE (PBAD): INSTRUMENT DEVELOPMENT
}

Ana TOKIĆ MILAKOVIĆ, Ninoslava PEĆNIK Faculty of Law, Zagreb

UDK: 159.922.8:316.356.2

Izvorni znanstveni rad

Primljeno: 14. 12. 2012.

The aim of the study was to develop an instrument for measuring the Parental Behaviors in the Context of Adolescent Disclosure (PBAD) and to examine its dimensionality, internal consistency, predictive and construct validity. The scale has been developed on the basis of a qualitative study of adolescents' views (Tokić \& Pećnik, 2011) and consists of 2 subscales: the PBAD-A (antecedents of disclosure) and PBAD-R (reactions to previous disclosures). It was implemented with 1074 adolescents (13-year-olds) from 50 schools in Croatia (probabilistic cluster sample). Adolescents also reported on disclosure about daily activities, feelings and concerns. Youth gave estimations for mothers and fathers separately. Latent structures of the PBAD-A and PBAD-R were interpretable and reasonably congruent for mothers and fathers. Factor analyses of the PBAD-A revealed three factors: Initiating conversation, Intrusiveness and Unavailability. Factor analyses of the PBAD-R yielded three factors: Support and respectful guidance, A let-down and Punishment. Internal consistency for all factors was acceptable $(0.75-0.92)$. All except one of the extracted factors of the PBAD correlated with actual disclosure to mothers and fathers about daily activities, feelings and concerns significantly and in the predicted direction, which supports the predictive and construct validity of the instrument.

Keywords: parent-adolescent communication, adolescent self-disclosure, antecedents of disclosure, parental reactions to youth disclosure, parenting

$\triangle \quad$ Ana Tokić Milaković, University of Zagreb, Faculty of Law, Social Work Study Centre, Nazorova 51, 10000 Zagreb, Croatia. 
Parental knowledge about adolescents' daily activities has been shown to be linked to adolescents' adjustment, including both lower problem behavior and higher well-being. This link was frequently interpreted as resulting from parental active monitoring of adolescents' activities and whereabouts (see Dishion \& McMahon, 1998 for a review). However, recent research provided evidence that this knowledge had originated mainly from adolescents' spontaneous disclosure to parents (Kerr, Stattin, \& Burk, 2010; Stattin \& Kerr, 2000). Although self-disclosure represents a voluntary activity which depends on adolescent's characteristics, it is reasonable to presume that parental behaviors in the context of disclosure could especially encourage or discourage this process.

Research addressed contributions of general parenting dimensions in predicting adolescents' disclosure and found that adolescents disclosed more to warm, accepting and responsive parents (Blodgett Salafia, Gondoli, \& Grundy, 2009; Snoek \& Rothblum, 1979; Soenens, Vansteenkiste, Luyckx, \& Goossens, 2006), and less to the parents who tended to criticize them regularly (Rosenthal, Efklides, \& Demetriou, 1988), as well as to overly controlling parents (Kerr \& Stattin, 2000; Soenens et al., 2006). On the contrary, Smetana, Metzger, Gettman, and Campione-Barr (2006) found parental psychological control to predict more disclosure of personal issues. However, among all parenting dimensions, the largest effect on self-disclosure was found for parental responsiveness (Soenens et al., 2006).

Less is known about the links of self-disclosure with particular parental behaviors specifically involved in the disclosure-related interaction. According to dynamic transactional perspectives of relationship development (Kuczynski \& Parkin, 2009), people expect others to behave in certain ways on the basis of their behaviors in similar past interactions (Hinde, 1979). Therefore, youths' decisions whether to disclose or not, are partly based on the history of parental reactions to their disclosures in the past. In line with that, two qualitative studies showed that one of the most prominent reasons adolescents gave for withholding information was expecting negative reactions from their parents (Marshall, Tilton-Weaver, \& Bosdet, 2005; Tilton-Weaver \& Marshall, 2008). Very few quantitative studies explored parental reactions to youths' disclosures (Kerr, Stattin, \& Trost, 1999; Tilton-Weaver et al., 2010), and none of them thoroughly described and classified such parental reactions. Apart from the reactions following adolescents' disclosures, parental emotional states or behaviors that take place prior to actual self-disclosure also play a role in inviting or preventing adolescents' opening up to a parent (Tokić \& Pećnik, 2011). 
DRUŠ. ISTRAŽ. ZAGREB GOD. 23 (2014), BR. 1 STR. 67-85

TOKIĆ MILAKOVIĆ, A., PEĆNIK, N.: PARENTAL BEHAVIORS.
Within this study, we aimed to develop an instrument measuring specific parental behaviors occurring in the context of adolescent everyday disclosures that might facilitate or inhibit adolescents' subsequent disclosures. This would add the contextual specificity to the prevailing parenting measures assessing general parenting dimensions and enable a more refined analysis of adolescent disclosure to parents on the micro level. Therefore, the aim of the present study was to develop an instrument for measuring Parental Behaviors in the Context of Adolescent Disclosure (PBAD) and to explore its dimensionality, internal consistency, predictive and construct validity.

\section{GENERATION OF ITEMS}

In line with constructivist perspective, it is crucial to acknowledge that adolescents do not react to parental behaviors per $s e$, but they give a certain meaning to parental actions and actually react to their own construction of the situation. Regardless of the actual intentions that have guided certain parental acts, the adolescent's reactions tend to be in accordance with their interpretations of these acts (and intentions). Therefore, we argued that the best input for generation of items could be given by adolescents themselves.

We were interested both in behaviors preceding disclosure, and past or anticipated parental reactions following disclosure. In order to explore the adolescents' perceptions of parental behaviors affecting their disclosure, four focus groups with adolescents aged 13 to 14 were conducted (for detailed report see Tokić \& Pećnik, 2011). This particular age was targeted, because by then, self-disclosure to parents had already started to decrease (Buhrmester \& Prager, 1995) and adolescents oriented themselves more to their peers (Csikszentmihalyi \& Larson, 1984).

The participants were asked to recall a situation in which they disclosed to their parent and to describe the occurred parental behaviors (if any) that encouraged them to do so (Tokić \& Pećnik, 2011). They were also invited to recall a situation in which they decided not to disclose to their parent, and to report about parental behaviors that discouraged them from disclosing. Different types of situations, in which disclosure to parents might take place, were covered: disclosure of daily activities, intimate self-disclosure, disclosure of disapproved activities and non-disclosure.

On the basis of adolescents' accounts, we developed a preliminary version of the PBAD scale. Whenever possible, adolescents' own words were used to create items. Parental behaviors described within the items were grouped into two scales: antecedents of disclosure (PBAD-A; Table 1) and reactions to 
DRUŠ. ISTRAŽ. ZAGREB GOD. 23 (2014), BR. 1, STR. 67-85

TOKIĆ MILAKOVIĆ, A., PEĆNIK, N.

PARENTAL BEHAVIORS... disclosure (PBAD-R; Table 2). The preliminary version of the instrument had been administered in a pilot study to a sample of 263 boys and girls (13-14 year olds). Problematic items were dropped out or replaced on the basis of content incomprehensibility and/or psychometric properties (Tokić Milaković, 2014).

Parental antecedents of adolescents' disclosure (PBAD-A items) were formed to represent dominant categories of mothers' and fathers' behaviors perceived by adolescents to have preceded and influenced their self-disclosures, which were identified by a content analysis of focus groups material (Tokić \& Pećnik, 2011). Those categories were: asking unobtrusive questions (items $1 / 6 / 15)$, creating opportunities for adolescent's disclosure (9), recognizing adolescent's emotional state (17), inviting unconditional disclosure (5), parental own self-disclosure (2/10/12), unavailability (3/7/11/14) and intrusiveness (4/8/13/16).

Parental reactions to adolescents' disclosure (PBAD-R items) were formed to describe the dominant categories of mothers' and fathers' behaviors perceived by adolescents as following their previous and influencing their subsequent self-disclosures (Tokić \& Pećnik, 2011). They can generally be divided into positive and negative reactions. Positive reactions were represented by emotional support (item 5), having fun with adolescent (2/8), emphatic understanding (29), attentive listening (10/19), appreciating adolescent's disclosure (15), taking adolescent seriously (11), trust in adolescent's competence (5/18), constructive feedback (1/27/30), instrumental support (13), calm reaction (21), negotiating (25/22). Negative reactions were represented by distraction and interrupting (items 7/9), frivolousness (6/14), showing mistrust in adolescent (3), anger and yelling (4/20/24), punishment (17/31/23/26), lecturing (28), silent treatment (32), lack of understanding (12) and panicking about adolescent's problem (16).

\section{METHOD}

\section{Participants and procedure}

The participants were seventh graders recruited during February and March 2010, from 50 schools in Croatia via cumulative size method of sampling (Lohr, 2009). The sample was selected from the population of all seventh-grade classes in primary schools in Croatia. Implicit stratification was present because the sampling frame was ordered by county, which kept the regional structure representative. Out of all enrolled pupils in the chosen sample, 1074 agreed to participate in the study and had an active parent informed consent (89.6\%). Most of the participants lived with both mother and father $(88.6 \%)$. 
DRUŠ. ISTRAŽ. ZAGREB GOD. 23 (2014), BR. 1 STR. 67-85

TOKIĆ MILAKOVIĆ, A., PEĆNIK, N.: PARENTAL BEHAVIORS.
The mean age of their parents was 44.2 years for fathers, and 40.8 years for mothers. The attained educational level of their parents was predominantly a high school degree $(62.6 \%$ of mothers; $70.6 \%$ of fathers); only $16 \%$ of mothers and $16.4 \%$ of fathers had university degree.

Out of the 1074 students, 28 did not respond to the part of the questionnaire concerning mothers and 43 students to the questions concerning fathers (due to lack of contact). Furthermore, invalid responses were excluded from the analysis, having left a total of 1008 students with usable data for mothers (497 boys and 511 girls), and 989 students with usable data for fathers ( 489 boys and 500 girls). The mean age of the sample was 13.4 years.

The study was approved by the Ethical Board of the Faculty of Law. The questionnaires were filled in during the usual class hours. The questionnaire consisted of three parts: 1) about adolescent, 2) about mother, and 3) about father. The order of the parts 2 and 3 were rotated on the class level.

\section{Measures}

The Parental Behaviors in the Context of Adolescent Disclosure (PBAD) comprises two subscales: 1) PBAD-A (antecedents) and 2) PBAD$-R$ (reactions to disclosures). ${ }^{1}$

The PBAD-A consists of 17 items. Nine items describe parental emotional states or behaviors presumed to facilitate adolescent disclosure (inviters), and eight items describe inhibiting parental states and behaviors (inhibitors). Participants were asked to assess how often their mother/father behaved in the following ways (e.g. She asks me what's new) on a five-point response scale (1-never, 5-always).

PBAD-R consists of 32 items, half of which describe positive parental reactions, and the other half negative parental reactions to youth disclosure. As parents may react differently to different types of disclosures, items in the questionnaire were divided into three subgroups: 1) reactions to positive happenings (e.g. She is truly joyful for me; She devaluates the accomplishments I tell her about), 2) reactions to problems and worries (e.g. She gives me some good advice; She gets too upset and panicky about my problem), and 3) reactions to wrongdoings (e.g. She ignores me when I try to explain; She clearly explains the possible consequences of my behavior). Each group of reactions had a specific instruction ahead. The youth were asked to assess for each item how often their mother/father reacted to disclosure in the described ways.

Disclosure about daily activities (Kerr \& Stattin, 2000; Stattin \& Kerr, 2000) was measured by a five-item scale (e.g. Do you tell your mum about your friends - which friends you hang 
DRUŠ. ISTRAŽ. ZAGREB GOD. 23 (2014), BR. 1, STR. 67-85

TOKIĆ MILAKOVIĆ, A., PEĆNIK, N.

PARENTAL BEHAVIORS... out with and how they think and feel about various things?). Five-point response scales were used (1-never to 5-always). Several studies found a two-factor structure of the scale: disclosure and secrecy (Frijns, Keijsers, Branje, \& Meeus, 2010; Tilton-Weaver et al., 2010), pointing out the importance of conceptually distinguishing between the two. Since it is not yet clear whether this structure stems from conceptual difference between disclosure and secrecy or it represents a disclosure topic specificity (disclosure items concern school and friends; secrecy items concern free time, nights and weekends), we rephrased the two secrecy items to measure disclosure (e.g. "Do you hide..?" was changed to "Do you tell...?"). The Alpha reliability for this scale was 0.88 for disclosure to mothers and 0.87 for disclosure to fathers.

Disclosure about feelings and concerns (Kerr et al., 1999) was measured by the eight-item scale (e.g. Do you talk to your mum about intimate matters?). During translation, we dropped out the adverbs of frequency (e.g. often) because they had already been included in the five-point response scale (1-never to 5-always). The Alpha reliability for this scale was 0.93 for disclosure to mothers and 0.91 for disclosure to fathers.

\section{RESULTS}

\section{Factor structure of PBAD-A and PBAD-R}

In order to examine the dimensionality of the scale Parental Behaviors in Context of Adolescent Disclosure, both for antecedents (PBAD-A) and reactions to disclosure (PBAD-R), as well as in order to reduce the data collected to a smaller set of latent variables, four exploratory factor analyses (principal axis factoring) have been conducted: the PAF of the PBAD-A on adolescents' assessments for mothers, the PAF of the PBAD-A on adolescents' assessments for fathers, the PAF of the PBAD-R on adolescents' assessments for mothers and the PAF of the PBAD-R on adolescents' assessments for fathers.

\section{Factor analysis of PBAD-A}

Prior to performing the PAF on 17 items of the PBAD-A, suitability of the data for factor analysis was assessed; the Kaiser-Meyer-Olkin value was 0.85 for the data concerning mothers, and 0.86 for father-data, supporting the factorability of both correlation matrices.

Adolescents' PBAD-A assessments of mothers. The factor analysis revealed four factors with initial eigenvalues exceeding 1 , explaining $21.5 \%, 16.5 \%, 4.1 \%$ and $2.8 \%$ of the shared variance respectively. After performing the Direct oblimin rotation, an interpretable structure occurred, with the items in 
DRUŠ. ISTRAŽ. ZAGREB GOD. 23 (2014), BR. 1 STR. 67-85

TOKIĆ MILAKOVIĆ, A. PEĆNIK, N PARENTAL BEHAVIORS.

(1) TABLE 1

Pattern Matrix for factor analysis of the Three Factor Solution of PBAD-A items for adolescents' reports about mothers and fathers (Parental antecedents of disclosures) brackets loading higher than 0.3: 1. Inviting disclosure (items 6/5/1/17/15/9), 2. Intrusiveness (items 16/13/8/4), 3. Unavailability (items 14/7/11/3), 4. Parental disclosure (items 12/10/2). However, the results of the parallel analysis (Watkins, 2000) revealed only three factors with eigenvalues surpassing the corresponding criterion values for a randomly generated data matrix of the same size (17 variables X 1008 subjects). On the basis of the parallel analysis, we decided to keep only the first three factors and repeated the PAF with the extraction based on the fixed number of factors. The three-factor solution explained $41.6 \%$ of the variance in total. The direct oblimin rotation revealed the presence of a simple structure (Thurstone, 1947) with almost all items loading 0.3 or more on only one factor (Table 1). It can be noted that the fourth factor merged with the first factor in the three-factor solution. The correlations between the extracted factors were relatively low to moderate $(\mathrm{r} 12=0.05, \mathrm{r} 13=-0.28, \mathrm{r} 23=0.47)$.

\begin{tabular}{|c|c|c|c|c|c|c|}
\hline \multirow[b]{2}{*}{ Extracted factors / Items $(\mathrm{k}=17)$} & \multicolumn{3}{|c|}{ Mothers $(\mathrm{N}=1008)$} & \multicolumn{3}{|c|}{ Fathers $(\mathrm{N}=989)$} \\
\hline & IC & I & $\mathrm{U}$ & IC & I & $\mathrm{U}$ \\
\hline \multicolumn{7}{|l|}{ 1. Initiating conversation } \\
\hline 12. She/he tells me about daily happenings in her/his life. & 0.759 & -0.029 & 0.155 & 0.720 & -0.047 & 0.109 \\
\hline $\begin{array}{l}\text { 10. She/he talks about her/his day at work (or at home } \\
\text { if she doesn't work). }\end{array}$ & 0.678 & -0.043 & 0.139 & 0.704 & -0.077 & 0.152 \\
\hline $\begin{array}{l}\text { 02. She/he tells me about some adventure } \\
\text { from her/his youth days. }\end{array}$ & 0.614 & -0.063 & 0.061 & 0.648 & -0.156 & 0.130 \\
\hline 15. She/he asks me if I've had a good time. & 0.562 & 0.077 & 0.025 & 0.583 & 0.178 & -0.065 \\
\hline 06. She/he asks me what's new. & 0.562 & -0.054 & -0.026 & 0.578 & 0.038 & -0.097 \\
\hline 09. She/he sits next to me so we can talk. & 0.558 & 0.196 & -0.269 & 0.543 & 0.208 & -0.230 \\
\hline 05. She/he says that I can tell her/him anything, & 0.497 & 0.039 & -0.141 & 0.521 & 0121 & -0207 \\
\hline 17. She/he notices if something is bothering me. & 0.458 & 0.105 & -0.195 & 0.504 & 0.148 & -0.227 \\
\hline 01. She/he asks me: "How was school today?" & 0.417 & -0.060 & -0.028 & 0.531 & 0.013 & -0.065 \\
\hline \multicolumn{7}{|l|}{ 2. Intrusiveness } \\
\hline $\begin{array}{l}\text { 16. When she/he wants to find out something, } \\
\text { she/he questions me until I tell. }\end{array}$ & 0.048 & 0.714 & -0.001 & 0.055 & 0.640 & 0.060 \\
\hline 08. She/he puts pressure on me to tell her/him everything. & -0.086 & 0.673 & 0.122 & -0.105 & 0.746 & 0.103 \\
\hline $\begin{array}{l}\text { 04. When she/he wants to find out something about me, } \\
\text { she/he asks "police interrogation type" questions. }\end{array}$ & -0.050 & 0.657 & 0.065 & 0.065 & 0.520 & 0.178 \\
\hline 13. She/he asks me questions which are too personal. & 0.041 & 0.654 & 0.058 & 0.035 & 0.559 & 0.063 \\
\hline \multicolumn{7}{|l|}{ 3. Unavailability } \\
\hline 14. She/he is in a bad mood. & 0.030 & 0.087 & 0.683 & -0.021 & 0.110 & 0.632 \\
\hline 07. She/he's in a hurry. & -0.008 & 0.040 & 0.647 & -0.069 & 0.179 & 0.491 \\
\hline $\begin{array}{l}\text { 11. Someone else has made her/him angry, } \\
\text { so she/he's nervous. }\end{array}$ & 0.070 & 0.139 & 0.633 & 0.104 & 0.088 & 0.671 \\
\hline 03. She/he is preoccupied with other things than me. & -0.169 & 0.187 & 0.473 & -0.164 & 0.181 & 0.495 \\
\hline
\end{tabular}

Notes. IC - Initiating conversation; I - Intrusiveness; U - Unavailability

Adolescents' PBAD-A assessments of fathers. The factor ana- 
DRUŠ. ISTRAŽ. ZAGREB GOD. 23 (2014), BR. 1, STR. 67-85

TOKIĆ MILAKOVIĆ, A., PEĆNIK, N

PARENTAL BEHAVIORS... respectively. The results of the parallel analysis revealed all three factors with eigenvalues surpassing the corresponding criterion values for a randomly generated data matrix of the same size (17 variables X 989 subjects). The direct oblimin rotation revealed the presence of a simple structure, with all items loading 0.3 or more on only one factor (Table 1 ). The correlations between the extracted factors were low to moderate $(\mathrm{r} 12=0.17, \mathrm{r} 13=-0.26, \mathrm{r} 23=0.35)$.

The factor structures of the PBAD-A for mothers and fathers are congruent (see Table 1), and the interpretation of the extracted three factors is consistent with the rationale for the items generation presented in the introduction. The first extracted factor, labeled Initiating conversation, is represented by the items describing parental own self-disclosure, asking unobtrusive questions, creating opportunities for adolescent's disclosure, recognizing adolescent's emotional state and inviting unconditional disclosure. The items loading strongly on the second factor describe parental Intrusiveness, and the third factor is represented by the items describing parent's Unavailability.

\section{Factor analysis of PBAD-R}

Prior to conducting the factor analyses of the 32 items of the PBAD-R, the suitability of the data for factor analysis was assessed; the Kaiser-Meyer-Olkin value was 0.95 for the data concerning mothers and 0.94 for father-data.

Adolescents' PBAD-R assessments of mothers. Factor analysis revealed five factors with initial eigenvalues exceeding 1 , explaining $27.7 \%, 7.8 \%, 4.2 \%, 1.7 \%$ and $1.3 \%$ of the shared variance respectively. However, an inspection of the scree plot revealed a clear break after the third factor. This was supported by the results of the parallel analysis, which revealed only three factors with eigenvalues surpassing the corresponding criterion values for a randomly generated data matrix of the same size ( 32 variables $X 1008$ subjects). In total, the three-factor solution explained $39.3 \%$ of the variance. The direct oblimin rotation of the three-factor solution revealed the presence of a simple structure (Table 2). The correlations between the extracted factors were moderate $(\mathrm{r} 12=-0.46, \mathrm{r} 13=-0.27, \mathrm{r} 23=0.34)$.

Adolescents' PBAD-R assessments of fathers. Factor analysis revealed five factors with eigenvalues exceeding 1 , explaining $27.9 \%, 8.7 \%, 3.9 \%, 1.9 \%$ and $1.5 \%$ of the shared variance respectively. However, the results of the parallel analysis revealed only three factors with eigenvalues surpassing the corresponding criterion values for a randomly generated data matrix of the same size ( 32 variables $X 989$ subjects). Based $u-$ pon the parallel analysis and the inspection of scree plot, we decided to keep only the first three factors and repeated the PAF with the extraction based on the fixed number of factors. The three-factor solution explained $39.9 \%$ of the shared variance. 
(1) TABLE 2

Pattern Matrix of the Three Factor Solution of PBAD-R (Parental reactions to disclosure items for adolescents' reports about mothers and fathers
The direct oblimin rotation revealed the presence of a simple structure, with almost all items loading moderately or highly on only one factor (Table 2). The correlations between the extracted factors were moderate $(\mathrm{r} 12=-0.26, \mathrm{r} 13=-0.42, \mathrm{r} 23=0.38)$.

\begin{tabular}{|c|c|c|c|c|c|c|}
\hline \multirow{2}{*}{ Extracted factors / items $(\mathrm{k}=32)$} & \multicolumn{3}{|c|}{ Mothers $(\mathrm{N}=1008)$} & \multicolumn{3}{|c|}{ Fathers $(\mathrm{N}=989)$} \\
\hline & SRG & LD & $\mathrm{P}$ & SRG & $\mathrm{P}$ & $\mathrm{LD}$ \\
\hline \multicolumn{7}{|l|}{ 1. Support and respectful guidance } \\
\hline $\begin{array}{l}\text { b11. takes my worries and problems seriously. } \\
\text { b15. shows she's happy that I've taken }\end{array}$ & 0.762 & 0.103 & -0.026 & 0.747 & -0.106 & 0.102 \\
\hline her/him into my confidence. & 0.697 & 0.068 & -0.072 & 0.721 & -0.087 & 0.122 \\
\hline a2. is truly joyful for me. & 0.669 & 0.108 & -0.093 & 0.656 & -0.167 & 0.101 \\
\hline b13. gives me good advice. & 0.666 & 0.068 & -0.134 & 0.763 & -0.053 & 0.118 \\
\hline \multicolumn{7}{|l|}{ b18. points to my abilities and virtues that can help me } \\
\hline solve the problem. & 0.660 & 0.052 & 0.023 & 0.666 & 0.022 & -0.048 \\
\hline a10. listens to every detail with interest. & 0.655 & 0.028 & -0.084 & 0.698 & -0.074 & 0.077 \\
\hline \multicolumn{7}{|l|}{ a8. laughs with me at some funny events } \\
\hline I tell her/him about. & 0.617 & 0.096 & -0.112 & 0.594 & -0.101 & 0.031 \\
\hline a1. praises me. & 0.614 & 0.051 & -0.080 & 0.611 & -0.113 & 0.083 \\
\hline c27. encourages me to make things right somehow. & 0.589 & -0.235 & 0.193 & 0.610 & 0.206 & -0.233 \\
\hline b19. listens to me carefully, with no interruptions. & 0.588 & -0.038 & -0.093 & 0.659 & -0.122 & -0.046 \\
\hline \multicolumn{7}{|l|}{ c29. tries to understand what I was thinking and how } \\
\hline I felt when I did this. & 0.575 & -0.203 & 0.033 & 0.683 & 0.075 & -0.122 \\
\hline \multicolumn{7}{|l|}{ c22. gives me an opportunity to explain the reasons } \\
\hline of my behavior. & 0.553 & -0.166 & -0.059 & 0.579 & -0.011 & -0.146 \\
\hline a5. supports me in my decisions. & 0.531 & -0.015 & -0.141 & 0.596 & -0.093 & -0.019 \\
\hline \multicolumn{7}{|l|}{ c30. clearly explains the possible consequences } \\
\hline of my behavior. & 0.487 & -0.212 & 0.268 & 0.529 & 0.253 & -0.235 \\
\hline c25. respects my opinion even if she/he disagrees. & 0.411 & -0.115 & 0.107 & 0.467 & 0.098 & -0.098 \\
\hline c21. calmly expresses her/his disapproval. & 0.378 & -0.160 & 0.154 & 0.381 & 0.138 & -0.156 \\
\hline \multicolumn{7}{|l|}{ 2./3. A let-down } \\
\hline a6. devalues the accomplishments I tell her/him about. & 0.035 & 0.706 & -0.037 & -0.067 & -0.027 & 0.600 \\
\hline $\begin{array}{l}\text { a9. interrupts me and starts talking about something else. } \\
\text { b17. punishes me for something I've told her/him }\end{array}$ & -0.085 & 0.634 & 0.046 & -0.143 & 0.123 & 0.548 \\
\hline in confidence. & 0.065 & 0.612 & 0.117 & 0.074 & 0.097 & 0.551 \\
\hline a4. gets angry for something I've told her/him joyfully. & 0.010 & 0.583 & -0.009 & -0.004 & 0.055 & 0.567 \\
\hline b14. diminishes the importance of my problem. & -0.069 & 0.577 & 0.033 & -0.049 & -0.010 & 0.525 \\
\hline a3. doubts the truthfulness of what I tell her/him. & -0.040 & 0.576 & 0.013 & -0.025 & 0.101 & 0.498 \\
\hline b16. gets too upset and panics about my problem. & 0.059 & 0.545 & 0.179 & 0.070 & 0.150 & 0.518 \\
\hline a7. is focused on something else (TV, newspapers, & & & & & & \\
\hline SMS messages...) while I'm talking to her/hi & -0.155 & 0.506 & 0.129 & -0.214 & 0.142 & 0.381 \\
\hline b12. blames me for what has happened to me. & -0.009 & 0.442 & 0.338 & -0.040 & 0.354 & 0.372 \\
\hline \multicolumn{7}{|l|}{ 3./2. Punishment } \\
\hline c26. makes me feel guilty. & -0.107 & 0.125 & 0.616 & -0.104 & 0.558 & 0.122 \\
\hline c24. yells at me. & -0.098 & -0.013 & 0.605 & -0.126 & 0.667 & -0.056 \\
\hline c31. grounds me. & 0.023 & 0.078 & 0.568 & 0.069 & 0.530 & 0.103 \\
\hline c28. keeps reminding me of my mistake. & -0.068 & 0.137 & 0.551 & -0.002 & 0.491 & 0.219 \\
\hline c20. calls me names. & -0.117 & 0.142 & 0.405 & -0.130 & 0.526 & 0.074 \\
\hline c32. ignores me when I try to explain. & -0.140 & 0.287 & 0.373 & -0.104 & 0.462 & 0.249 \\
\hline c23. hits me. & -0.096 & 0.203 & 0.330 & -0.057 & 0.480 & 0.123 \\
\hline
\end{tabular}

Notes: 1. SRG - Support and respectful guidance; LD - A Let-down; P - Punishment; Note 2. A small letter in front of each item's ordinal number refers to one of the three different beginnings of the sentences: a - When I tell her about something nice that has happened to me, my MUM/DAD . . ; b - When I confide myself to MUM/ DAD about some problem that bothers me, she/he...; c - When I confess that I did something she disapproved of, my MUM/DAD... 
DRUŠ. ISTRAŽ. ZAGREB GOD. 23 (2014), BR. 1, STR. 67-85

TOKIĆ MILAKOVIĆ, A., PEĆNIK, N

PARENTAL BEHAVIORS...
Factor structures of the PBAD-R for mothers and fathers are relatively congruent, the same three factors have been extracted, and only the order of the factors varies. The first extracted factor encompasses all positive reactions and is represented by the items which describe the provision of "Support and respectful guidance". In the four-factor solution, support (items 2/11/1/13/10/15/5/8/18/19) and respectful guidance (items 30/21/29/27/22/25) were represented by two different factors, but in the three-factor solution, they merge into one big factor. The items loading strongly on the second factor (third factor for father assessments) represent negative parental reactions to disclosure that probably evoke a strong unpleasant feeling of disappointment in adolescents; therefore we have labeled this group of parental reactions "A let-down". This factor refers mainly to the parental reactions to youth disclosure of positive happenings or problems and worries. The third factor (the second one in assessments of fathers) is mostly represented by parental reactions that serve as a "Punishment", and these reactions refer exclusively to disclosure of wrongdoings. ${ }^{2}$

\section{Descriptive statistics for PBAD-A and PBAD-R factors}

The descriptive statistics for all PBAD-A and PBAD-R factors are presented in Table 3 . For each factor, t-test for dependent samples was used to test the differences in means between assessments of mothers and fathers. Cohen's d was calculated as an indicator of the effect size.
Descriptive statistics

for PBAD-A and PBAD-R factors

\begin{tabular}{|c|c|c|c|c|c|c|}
\hline \multirow[b]{2}{*}{ PBAD factors } & \multirow[b]{2}{*}{$\mathrm{k}$} & \multicolumn{2}{|c|}{$\begin{array}{r}\text { Mothers } \\
(\mathrm{n}=1008)\end{array}$} & \multicolumn{2}{|c|}{$\begin{array}{r}\text { Fathers } \\
(\mathrm{n}=989)\end{array}$} & \multirow[b]{2}{*}{ Cohen's d } \\
\hline & & $\mathrm{M}$ & $\overrightarrow{\mathrm{SD}}$ & $\mathrm{M}$ & $\mathrm{SD}$ & \\
\hline \multicolumn{7}{|l|}{ PBAD-A } \\
\hline Initiating conversation & 9 & $3.85^{* * *}$ & 0.707 & 3.53 & 0.803 & 0.42 \\
\hline Intrusiveness & 4 & $1.97^{* * *}$ & 0.889 & 1.79 & 0.806 & 0.21 \\
\hline Unavailability & 4 & 2.19 & 0.775 & $2.28^{* *}$ & 0.771 & -0.12 \\
\hline \multicolumn{7}{|l|}{ PBAD-R } \\
\hline Support and respectful guidance & 16 & $4.03^{* * *}$ & 0.679 & 3.86 & 0.754 & 0.24 \\
\hline A let-down & 9 & 1.78 & 0.718 & 1.77 & 0.661 & 0.01 \\
\hline Punishment & 7 & $1.70^{* * *}$ & 0.648 & 1.62 & 0.636 & 0.12 \\
\hline
\end{tabular}

Note: The differences in means between mothers and fathers have been tested for each factor by t-test for dependent samples. Statistically higher means have been marked by asterisks $\left({ }^{* *} \mathrm{p}<0.001 ;{ }^{* *} \mathrm{p}<0.01 ;{ }^{*} \mathrm{p}<0.05\right)$; according to Cohen (1988), $\mathrm{d}=0.2$ refers to small, $\mathrm{d}=0.5$ to medium and $\mathrm{d}=0.8$ to large effect size.

According to the results of the conducted analyses, mothers are perceived to initiate more conversation with adolescents, but also as more intrusive than fathers. Fathers are seen as somewhat more frequently unavailable than mothers. In their reactions to youth self-disclosure, mothers are perceived to 
provide more support and respectful guidance than fathers but they also somewhat more frequently than fathers react by punishing adolescents for the disclosed wrongdoings.

\section{Internal consistency and predictive validity of PBAD-A and PBAD-R factors}

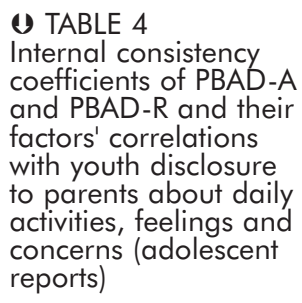

The internal consistency of each PBAD factor has been calculated separately for mother and father appraisals (Table 4). The Cronbach's alpha coefficients are respectably high for all PBAD-A and PBAD-R factors. There is no item whose deletion would result in higher internal consistency of the scale. However, due to a large number of items, the factor "Support and respectful guidance" has a potential to get shortened in further analyses without jeopardizing the internal consistency of the scale.

\begin{tabular}{|c|c|c|c|c|c|c|c|}
\hline \multirow[b]{2}{*}{ PBAD factors } & \multirow[b]{2}{*}{$\mathrm{k}$} & \multicolumn{2}{|c|}{ Cronbach's alpha } & \multicolumn{2}{|c|}{$\begin{array}{r}\text { Disclosure about } \\
\text { daily activities }\end{array}$} & \multicolumn{2}{|c|}{$\begin{array}{l}\text { Disclosure about } \\
\text { feelings and concern }\end{array}$} \\
\hline & & $\begin{array}{r}\text { Mothers } \\
(\mathrm{n}=1008)\end{array}$ & $\begin{array}{r}\text { Fathers } \\
(\mathrm{n}=989)\end{array}$ & $\begin{array}{r}\text { Mothers } \\
(\mathrm{n}=1008)\end{array}$ & $\begin{array}{r}\text { Fathers } \\
(\mathrm{n}=989)\end{array}$ & $\begin{array}{r}\text { Mothers } \\
(\mathrm{n}=1008)\end{array}$ & $\begin{array}{r}\text { Fathers } \\
(\mathrm{n}=989)\end{array}$ \\
\hline \multicolumn{8}{|l|}{ PBAD-A } \\
\hline Initiating conversation & 9 & 0.82 & 0.85 & $0.59^{* *}$ & $0.64^{* *}$ & $0.62^{* *}$ & $0.69^{* *}$ \\
\hline Intrusiveness & 4 & 0.80 & 0.76 & -0.05 & 0.05 & $-0.10^{* *}$ & 0.03 \\
\hline Unavailability & 4 & 0.77 & 0.75 & $-0.22^{* *}$ & $-0.21^{* *}$ & $-0.28^{* *}$ & $-0.27^{* *}$ \\
\hline \multicolumn{8}{|l|}{ PBAD-R } \\
\hline $\begin{array}{l}\text { Support and res- } \\
\text { pectful guidance }\end{array}$ & 16 & 0.91 & 0.92 & $0.50^{* *}$ & $0.55^{* *}$ & $0.59^{* *}$ & $0.62^{* *}$ \\
\hline A let-down & 9 & 0.86 & 0.82 & $-0.20^{* *}$ & $-0.17^{* *}$ & $-0.26^{* *}$ & $-0.19^{* *}$ \\
\hline Punishment & 7 & 0.80 & 0.81 & $-0.24^{* *}$ & $-0.20^{* *}$ & $-0.31^{* *}$ & $-0.25^{* *}$ \\
\hline
\end{tabular}

${ }^{* *} \mathrm{p}<0.001$

Since the instrument is aimed to measure the parental tendency to behave in the ways that facilitate/inhibit youth disclosure, the predictive validity is best to be demonstrated by correlations of the PBAD-A and PBAD-R factors with the youth actual disclosure. These correlations are presented in the Table 4 . As indicated, the best predictive validity was found for the two factors representing parental positive behaviors (antecedents and reactions): Initiating conversation and Support and respectful guidance. Predictive validity coefficients for most of other factors are rather small to moderate, but statistically significant $(p<0.001)$ and always in the expected direction. Intrusiveness seems to have very poor predictive validity for youth actual disclosure, with the exception of mothers' intrusiveness in predicting youth disclosure about feelings and concerns that reaches statistical significance.

Parents' gender seems to play a role when it comes to the correlation between parental behaviors in context of adolescents' disclosure and youths' actual disclosure. As noticeable 
DRUŠ. ISTRAŽ. ZAGREB STR. 67-85

TOKIĆ MILAKOVIĆ, A. PEĆNIK, N.

PARENTAL BEHAVIORS... GOD. 23 (2014), BR. 1,

from Table 4, fathers' "facilitating" behaviors (Initiating conversation, Support and respectful guidance) have consistently somewhat higher predictive validity coefficients than mothers' "facilitating" behaviors. On the other hand, predictive validity coefficients for mothers' "inhibiting" behaviors are mainly somewhat higher than the fathers'.

Using the Fisher transformation, we calculated whether the noticed differences between the correlation coefficients were statistically significant (one-sided test). The analyses showed that the difference was statistically significant for three out of six factors: Initiating conversation $(\mathrm{z}=-1.8 ; \mathrm{p}=0.036$ for daily activities; $\mathrm{z}=-2.74 ; \mathrm{p}=0.003$ for feelings and concerns), Intrusiveness $(\mathrm{z}=-2.23 ; \mathrm{p}=0.013$ for daily activities; $\mathrm{z}=-2.91 ; \mathrm{p}=0.002$ for feelings and concerns) and A let-down $(\mathrm{z}=-1.65 ; \mathrm{p}=0.049$ for feelings and concerns).

\section{DISCUSSION}

This study aimed at developing an instrument for measuring parental behaviors occurring in the context of adolescent disclosure that might facilitate or inhibit adolescents' subsequent disclosures, and at exploring its factor structure, internal consistency, predictive and construct validity.

The analyses showed that latent structures of the PBAD-A and PBAD-R were interpretable and reasonably congruent for mothers and fathers. However, the factor structure of the instrument for mothers can still be a subject of discussion. Although we decided to reject the fourth factor in the PBAD-A, as well as the fourth and fifth factor in the PBAD-R (on the basis of the parallel analysis), future research might provide further evidence that adolescents' representations of mothers' actions are somewhat more refined and differentiated than those of fathers'. The decision whether to use the three-factor solution or a solution with more factors might also depend on the purpose of the individual study. If a study aims at a detailed description of adolescents' perceptions of mothers' and fathers' behaviors, it might be reasonable to use a multi factor solution. However, if it aims at comparing mothers and fathers, or at searching for complex relations with other variables, it might be a priority to reduce the number of factors.

Internal consistency coefficients for all factors are acceptable. Most of the extracted factors of the PBAD correlate with actual disclosure to parents significantly and in the predicted direction, which supports the predictive and construct validity of the instrument.

Intrusiveness factor seems to be the only exception, having a rather low predictive validity (a significant, but rather small correlation was found only for mothers' intrusiveness 
DRUŠ. ISTRAŽ. ZAGREB GOD. 23 (2014), BR. 1 STR. 67-85

TOKIĆ MILAKOVIĆ, A., PEĆNIK, N.: PARENTAL BEHAVIORS.. and adolescents' disclosure about feelings and concerns). This is in contrast with the results of the qualitative study that preceded the development of the PBAD scale (Tokić \& Pećnik, 2011), where adolescents clearly referred to parental intrusiveness as annoying and as an inhibitor of their self-disclosure. However, this is not the first conflicting evidence concerning the relationship between parental intrusiveness and adolescents' disclosure. Namely, intrusiveness can be viewed as a mode of the mentioned general parenting dimension known as psychological control (Barber, 2002). Therefore, these contrasting results add to the unexplained conflicting findings of Soenens et al. (2006) who found a negative link, and Smetana et al. (2006) who found a positive link between parental psychological control and youth disclosure about personal issues. It might be that counteracting effects are at work here; children are not very prone to voluntarily and spontaneously self-disclose to intrusive parents, but also, intrusive parents sometimes "dig out" what they want to know - which manifests in a higher youth disclosure, too.

Similarly, previous research mainly found a small to moderate positive link between parental solicitation and youth's disclosure (Crouter, Bumpus, Davis, \& McHale, 2005; Keijsers, Frijns, Branje, \& Meeus, 2009; Stattin \& Kerr, 2000). However, as shown by the factor analysis of the PBAD-A, parental solicitation is a complex construct - it may be done in an intrusive or unobtrusive way. What probably matters to adolescents more than the question itself, is the manner of asking. This especially concerns the degree of adolescent's control over (not) answering, which is implied by the manner of asking. Thus, the open-ended questions (items 1/6/15) are much less intrusive than the "police interrogation style" questions (item 4). Therefore, the first ones merge into the Initiating conversation, which is perceived by adolescents as communicating care and interest, while the latter one comes under the Intrusiveness factor and is probably perceived as a privacy invasion (Petronio, 2002). This finding is in line with the results of the qualitative study that preceded the instrument development (Tokić \& Pećnik, 2011), where adolescents clearly explained how parents' questions were sometimes welcome and sometimes perceived as intrusive and experienced as parents "putting pressure" on the adolescent. As suggested by Grolnick, Beiswenger, and Price (2008), parental involvement is usually viewed as desirable, but only if the parent also supports the adolescent's autonomy.

The best predictive validity was found for the two factors representing parental positive behaviors: Initiating conversation and Support and respectful guidance. Although a certain 
DRUŠ. ISTRAŽ. ZAGREB GOD. 23 (2014), BR. 1, STR. 67-85

TOKIĆ MILAKOVIĆ, A., PEĆNIK, N

PARENTAL BEHAVIORS... proportion of this correlation may be attributed to the respondents' variability in self-enhancement tendencies (Paulhus \& Reid, 1991), the remaining proportion of the shared variance between the PBAD measures and youth disclosure serves as a demonstration of a good predictive and construct validity of the instrument.

The major limitation of this work concerns data collection in one time point only. This disables us to measure the test-retest reliability of the scale, and also limits the accuracy of the predictive validity assessment. In future research, the predictive validity of the PBAD should be tested longitudinally.

Also, the reactions in PBAD-R refer to three categories of self-disclosures (positive happenings, problems/worries, wrongdoings). The factor analyses have grouped all parental negative reactions to disclosures of wrongdoings into one factor $(\mathrm{Pu}-$ nishment), while negative reactions to positive happenings, problems and worries into another (A let-down). Positive parental reactions seem to be less disclosure-content-specific. In future research, it would be helpful to obtain the information on frequency of disclosure in the three content categories to entangle possible confounded relations between the content of disclosure and parental reactions.

Despite the limitations, the study significantly adds to the existing literature dealing with the adolescent-parent relationships in numerous ways. First, it presents a newly developed instrument of parental behaviors that goes beyond measuring general parenting dimensions (e.g. parental warmth), and is intended to be used by the researchers interested in the adolescent-parent transactions on the micro-level. Extracted factors encompass specific parental behavior patterns in the context of the child disclosure that, according to dynamic transactional perspective (Kuczynski \& Parkin, 2009), might be crucial for adolescents' construction of the view of "the parent as a disclosure target" and influence their decisions to disclose in the future. Using the PBAD in the upcoming longitudinal studies could contribute to testing dynamic transactional postulates in the specific micro-level context of youth disclosure to parents.

The new instrument provides operationalization of parental behaviors which are important in the process of the parent-adolescent communication. In addition to the parental negative reactions identified in previous research (Kerr et al., 1999; Marshall et al., 2005; Tilton-Weaver et al., 2010), new forms of parental behavior which play a role in facilitating adolescent disclosure have been introduced in the PBAD-A (i.e. creating opportunities for adolescent's disclosure, asking unobtrusive questions, parental own disclosure) and PBAD-R (i.e. attentive listening, constructive feedback). 
DRUŠ. ISTRAŽ. ZAGREB GOD. 23 (2014), BR. 1 STR. 67-85

TOKIĆ MILAKOVIĆ, A., PEĆNIK, N PARENTAL BEHAVIORS.
Second, the scale is the result of the mixed method approach. The items were developed on the basis of adolescents own words and insights collected in a qualitative study (Tokić \& Pećnik, 2011) and then applied to a representative sample of young adolescents in Croatia. Therefore, the major strength of this scale is that the items stem from adolescents' accounts, and are minimally contaminated by researchers' knowledge and personal biases. Furthermore, we believe that this approach to item generation facilitates the expression of the "child's perspective" on parent-child interaction in quantitative studies of parenting.

Third, the data were collected on a relatively large and representative sample of the whole of Croatia. Further research should test whether the same factor structure, predictive and construct validity remain on the samples in different countries and cultures.

Fourth, the scale has been designed to allow the rating of mothers and fathers separately, rather than asking for a joint rating for both parents. The research indicates that in studying the parenting of adolescents it is not justified to treat mothers and fathers as a single entity because they have unique and different relationships with adolescents (Laible \& Carlo, 2004). This is supported by our findings in terms of mean differences between mothers and fathers on most factors (see Table 3). In addition, in predicting adolescent's disclosure to a parent, predictive validity coefficients for some factors differ for mothers and fathers (Table 4). Initiating conversation has significantly higher validity in predicting adolescent's disclosure for fathers than for mothers. On the other hand, the predictive validity coefficients for mothers' "inhibiting" behaviors Intrusiveness and A let-down are larger than for fathers', especially in the context of disclosing feelings and concerns. We speculate that these differences in predictive validity coefficients between mothers and fathers may stem from differences in variances of mothers' and fathers' appraisals. Since relationships with mothers are typically described as close, intimate and supportive, and relationships with fathers as more distant (Youniss \& Smollar, 1985), we might expect adolescent appraisals of fathers to mutually differ more on "facilitating" behaviors (initiating conversation), while mothers differ more on "inhibiting" behaviors (intrusiveness, a let-down). Standard deviations in the Table 3 are in line with this assumption. However, these speculations should be further investigated in future research.

Furthermore, the PBAD-A and PBAD-R scales have a potential to be upgraded in the future by creating a parental version of the scale. With respect to the need for further understanding of the parent's and the child's role in shaping pa- 
DRUŠ. ISTRAŽ. ZAGREB GOD. 23 (2014), BR. 1, STR. 67-85

TOKIĆ MILAKOVIĆ, A., PEĆNIK, N

PARENTAL BEHAVIORS... rent-child interactions, it would be useful to learn more about the similarities and differences in their constructions of the same situations. Having child- and parent-versions of the scale would enable comparing child's and parent's understandings of the same parent's behaviors in the context of child's disclosure.

In conclusion, the new instrument enables further research of the bidirectional parent-adolescent interaction predictive of adolescent disclosure and it can be useful in applied research. Parental behaviors, child's understandings or feelings evoked by these behaviors, and child's disclosure are important issues for many parenting support programs. The new instrument provides means to assess the strengths (i.e. initiating conversation, providing support and respectful guidance) and weaknesses (i.e. intrusiveness, unavailability, a letdown, punishment) in "parent to child" communication in the situations of child's (non)disclosure of his/her concerns. Therefore, the PBAD may be an appropriate measure in outcome evaluation of interventions aimed at improving the quality of parent-adolescent communication and relationship.

\footnotetext{
1 Original questionnaire available upon request.
}

2 In additional analyses, PAF on the antecedents and reactions altogether have resulted in very similar factor solutions. However, items 5, 9 and 17 (PBAD-A) loaded more on the Support and respectful guidance factor than Initiating conversation factor. We have also tested the measurement invariance across the youths' gender. We found almost the same three-factor structure (having reduced the number of factors according to scree plots and parallel analyses) among girls and boys for PBAD-R, both on data concerning mothers and fathers. Regarding the PBAD-A, factor solutions for boys and girls are very similar to those gained on the whole sample (four factors, where one factor might be excluded according to parallel analysis). Only in the father-son dyad, the PAF on PBAD-A items resulted in two meaningful factors (facilitators and inhibitors). However, a refined analysis based on gender is beyond the scope of this paper.

\section{REFERENCES}

Barber, B. K. (2002). Intrusive parenting: How psychological control affects children and adolescents. Washington, DC: American Psychological Association. doi:10.1037/10422-000

Blodgett Salafia, E. H., Gondoli, D. M., \& Grundy, A. M. (2009). The longitudinal interplay of maternal warmth and adolescents' self-disclosure in predicting maternal knowledge. Journal of Research on Adolescence, 19(4), 654-668. doi:10.1111/j.1532-7795.2009.00615.x

Buhrmester, D., \& Prager, K. (1995). Patterns and functions of self-disclosure during childhood and adolescence. In K. J. Rotenberg (Ed.), 
DRUŠ. ISTRAŽ. ZAGREB GOD. 23 (2014), BR. 1 STR. 67-85

TOKIĆ MILAKOVIĆ, A., PEĆNIK, N. PARENTAL BEHAVIORS.
Disclosure processes in children and adolescents (pp. 10-56). Cambridge: Cambridge University Press. doi:10.1017/CBO9780511527746.002

Crouter, A. C., Bumpus, M. F., Davis, K. D., \& McHale, S. M. (2005). How do parents learn about adolescents' experiences? Implications for parental knowledge and adolescent risky behavior. Child Development, 76(4), 869-882. doi:10.1111/j.1467-8624.2005.00883.x

Csikszentmihalyi, M., \& Larson, R. (1984). Being adolescent: Conflict and growth in the teenage years. New York: Basic Books.

Dishion, T. J., \& McMahon, R. J. (1998). Parental monitoring and the prevention of child and adolescent problem behavior: A conceptual and empirical formulation. Clinical Child and Family Psychology Review, 1(1), 61-75. doi:10.1023/A:1021800432380

Frijns, T., Keijsers, L., Branje, S., \& Meeus, W. (2010). What parents don't know and how it may affect their children: Qualifying the disclosure-adjustment link. Journal of Adolescence, 33(2), 261-270. doi:10. 1016/j.adolescence.2009.05.010

Grolnick, W. S., Beiswenger, K. L., \& Price, C. E. (2008). Stepping up without overstepping: Disentangling parenting dimensions and their implications for adolescent adjustment. In M. Kerr, H. Stattin, \& R. C. M. E. Engels (Eds.), What can parents do? New insights into the role of parents in adolescent problem behavior (pp. 211-237). Chichester: John Wiley \& Sons.

Hinde, R. A. (1979). Towards understanding relationships. London: Academic Press.

Keijsers, L., Frijns, T., Branje, S., \& Meeus, W. (2009). Developmental links of adolescent disclosure, parental solicitation, and control with delinquency: Moderation by parental support. Developmental Psychology, 45(5), 1314-1327. doi:10.1037/a0016693

Kerr, M., \& Stattin, H. (2000). What parents know, how they know it, and several forms of adolescent adjustment: Further support for a reinterpretation of monitoring. Developmental Psychology, 36(3), 366-380. doi:10.1037/0012-1649.36.3.366

Kerr, M., Stattin, H., \& Burk, W. J. (2010). A reinterpretation of parental monitoring in longitudinal perspective. Journal of Research on Adolescence, 20(1), 39-64. doi:10.1111/j.1532-7795.2009.00623.x

Kerr, M., Stattin, H., \& Trost, K. (1999). To know you is to trust you: Parents' trust is rooted in child disclosure of information. Journal of Adolescence, 22(6), 737-752. doi:10.1006/jado.1999.0266

Kuczynski, L., \& Parkin, C. M. (2009). Pursuing a dialectical perspective on transaction: A social relational theory of micro family processes. In A. Sameroff (Ed.), The transactional model of development: How children and contexts shape each other (pp. 247-268). Washington: American Psychological Association. doi:10.1037/11877-013

Laible, D. J., \& Carlo, G. (2004). The differential relations of maternal and paternal support and control to adolescent social competence, self-worth, and sympathy. Journal of Adolescent Research, 19(6), 759-782. doi:10.1177/0743558403260094 
DRUŠ. ISTRAŽ. ZAGREB GOD. 23 (2014), BR. 1, STR. $67-85$

TOKIĆ MILAKOVIĆ, A. PECNIK, N.: PARENTAL BEHAVIORS...
Lohr, S. L. (2009). Sampling: Design and analysis. Pacific Grove: Duxbury Press.

Marshall, S. K., Tilton-Weaver, L. C., \& Bosdet, L. (2005). Information management: Considering adolescents' regulation of parental knowledge. Journal of Adolescence, 28(5), 633-647. doi:10.1016/j.adolescence.2005.08.008 Paulhus, D. L., \& Reid, D. B. (1991). Enhancement and denial in socially desirable responding. Journal of Personality and Social Psychology, 60(2), 307-317. doi:10.1037/0022-3514.60.2.307

Petronio, S. S. (2002). Boundaries of privacy: Dialectics of disclosure. Albany, NY: University of New York Press.

Rosenthal, D. A., Efklides, A., \& Demetriou, A. (1988). Parental criticism and young adolescent self-disclosure: A cross-cultural study. Journal of Youth and Adolescence, 17(1), 25-39. doi:10.1007/BF01538722

Smetana, J. G., Metzger, A., Gettman, D. C., \& Campione-Barr, N. (2006). Disclosure and secrecy in adolescent-parent relationships. Child Development, 77(1), 201-217. doi:10.1111/j.1467-8624.2006.00865.x

Snoek, D., \& Rothblum, E. (1979). Self-disclosure among adolescents in relation to parental affection and control patterns. Adolescence, 14 (54), 333-340.

Soenens, B., Vansteenkiste, M., Luyckx, K., \& Goossens, L. (2006). Parenting and adolescent problem behavior: An integrated model with adolescent self-disclosure and perceived parental knowledge as intervening variables. Developmental Psychology, 42(2), 305-318. doi:10.1037/0012-1649.42.2.305

Stattin, H., \& Kerr, M. (2000). Parental monitoring: A reinterpretation. Child Development, 71(4), 1072-1085. doi:10.1111/1467-8624.00210

Thurstone, L. L. (1947). Multiple factor analysis. Chicago: Chicago University Press.

Tilton-Weaver, L. C., \& Marshall, S. K. (2008). Adolescents' agency in information management. In M. Kerr, H. Stattin, \& R. C. M. E. Engels (Eds.), What can parents do? New insights into the role of parents in adolescent problem behavior (pp. 11-41). Chichester: John Wiley \& Sons.

Tilton-Weaver, L., Kerr, M., Pakalniskeine, V., Tokic, A., Salihovic, S., \& Stattin, H. (2010). Open up or close down: How do parental reactions affect youth information management? Journal of Adolescence, 33(2), 333-346. doi:10.1016/j.adolescence.2009.07.011

Tokić, A., \& Pećnik, N. (2011). Parental behaviors related to adolescents' self-disclosure: Adolescents' views. Journal of Social and Personal Relationships, 28(2), 201-222. doi:10.1177/0265407510382320

Tokić Milaković, A. (2014). The role of adolescents' characteristics and parental behavior in predicting self-disclosure to parents. (Unpublished doctoral dissertation). University of Zagreb, Faculty of Humanities and Social Sciences, Department of Psychology, Zagreb.

Watkins, M. W. (2000). Monte Carlo PCA for parallel analysis (computer software).

Youniss, J., \& Smollar, J. (1985). Adolescent relations with mothers, fathers, and friends. Chicago: University of Chicago Press. 
DRUŠ. ISTRAŽ. ZAGREB GOD. 23 (2014), BR. 1 STR. 67-85

TOKIĆ MILAKOVIĆ, A., PEĆNIK, N

PARENTAL BEHAVIORS..

\section{Percepcija roditeljskoga ponašanja $u$ kontekstu samootkrivanja adolescenata (PRPSO): razvoj instrumenta}

Ana TOKIĆ MILAKOVIĆ, Ninoslava PEĆNIK Pravni fakultet, Zagreb

Cili je ovog istraživanja bio razviti instrument za mjerenje adolescentske percepcije roditeljskoga ponašanja u kontekstu samootkrivanja (PRPSO) te ispitati njegovu dimenzionalnost, unutarnju konzistenciju, prediktivnu i konstruktnu valjanost. Skala je konstruirana na temelju rezultata kvalitativnog istraživanja s adolescentima (Tokić i Pećnik, 2011) i sastoji se od dvije podskale: PRPSO-A (antecedenti samootkrivanja) i PRPSO-R (reakcije na prethodna samootkrivanja). Skalu su ispunila 1074 adolescenta (trinaestogodišnjaci) iz 50 škola u Hrvatskoj (probabilistički klasterski uzorak). Adolescenti su također izvijestili o samootkrivanju o dnevnim aktivnostima, osjećajima i brigama. Procjene su dali posebno za očeve, a posebno za majke. Latentne strukture PRPSO-A i PRPSO-R dobivene na procjenama majki i očeva interpretabilne su $\mathrm{i}$ kongruentne. Faktorska analiza PRPSO-A otkrila je tri faktora: Iniciranje razgovora, Intruzivnost i Nedostupnost. Faktorska analiza PRPSO-R rezultirala je također trima faktorima: Podrška i uvažavajuće vodstvo, Iznevjerenje i Kažnjavanje. Unutarnja konzistencija za sve faktore prihvatliiva je $(0,75-0,92)$. Svi osim jednoga ekstrahiranog faktora skale PRPSO statistički su značajno povezani s aktualnim samootkrivanjem majkama i očevima o dnevnim aktivnostima, osjećajima i brigama u predviđenom smjeru, što ide u prilog prediktivnoj i konstruktnoj valjanosti instrumenta.

Ključne riječi: komunikacija između roditelja i adolescenata, samootkrivanje adolescenata, antecedenti samootkrivanja, roditeljske reakcije na samootkrivanje, roditeljstvo 